\section{Wojciech Śmieja}

Uniwersytet Śląski w Katowicach

\title{
Antynomie męskości i erotyczne spojrzenie na męskie ciało w Agnieszce, córce Kolumba Wilhelma Macha
}

\section{Abstract \\ Antinomies of Masculinity and the Eroticized Gaze on a Male Body in Agnieszka, córka Kolumba by Wilhelm Mach}

Wilhelm Mach's novel Agnieszka, córka Kolumba [Agnes, Columbus' Daughter] (1965) has now largely been forgotten, like the author's other works, yet, in the 1960's it used to be highly controversial and provoked numerous arguments. This paper brings the novel back into focus and analyzes the ambiguous and internally incongruous concept of masculinity it presents. The analysis concerns the novel both in the wider contexts of the ideological and aesthetic discussions of the 1960s, and in relation to the author's earlier works. The author's personal view on the form of a novel was highly interesting as he conceptualized a well-crafted novel as a "gendered" one: the "masculine" dimension of the epic had to be balanced by the "feminine" element encapsulated in the concentration on details, emotionality, and attentiveness. These ideas being put into practice, "the feminine" in Agnieszka is realized by the romantic plot and eroticization of the constructed-as-feminine gaze on the masculine body, yet under the heteronormative and patriarchal regime the eroticization of this body disrupts the "masculine" narrative and results in an artistic failure and the omnipresent misunderstanding of the author's intentions.

Słowa kluczowe: męskość, homoseksualność, queer gaze, powieść społeczno-obyczajowa

Keywords: masculinity, homosexuality, queer gaze, novel of manners 
Prześledzenie dorobku powieściowego Wilhelma Macha pozwala odkrywać w nim pisarza poszukującego nowych rozwiązań powieściowych, a zarazem pisarza próbującego wpisywać się w dominujące trendy: debiutancka (choć wydana z opóźnieniem) $R d z a$ (1950) to osadzona w przedwojennym jeszcze psychologizmie powieść „rozrachunków inteligenckich”, Jaworowy dom (1954) oscyluje wokół poetyki socrealistycznej i opowieści o awansie społecznym, Życie duże i małe (1959) zapowiada literaturę „nurtu chłopskiego”, ale poprzez figurę dziecięcego naiwnego narratora mamy w nim do czynienia z iście schulzowską „mityzacją rzeczywistości”. Najsłynniejsza powieść Macha - Góry nad czarnym morzem z 1961 roku - jest chyba jedyną, która nawiązuje do poszukiwań awangardowych. Ówcześni recenzenci, nie umiejąc znaleźć dla niej odpowiedników w przestrzeni literatury rodzimej, określali ją jako polski odpowiednik nouveau roman i zestawiali z twórczością głośnych wówczas Michela Butora i Alaina Robbe-Grilleta. Z leksykonów i kompendiów literaturoznawczych epoki, takich jak Włodzimierza Maciąga, można dowiedzieć się, że Góry były najradykalniejszym eksperymentem powieściowym Macha ${ }^{1}$. Istotnie, poetyka tego utworu $\mathrm{z}$ jego autotematyzmem, poznawczym zwątpieniem, rozmnożeniem instancji narracyjnych, partiami eseistycznymi, kompromitowaniem tradycyjnego wzorca powieści może taką analogię wywoływać, niemniej - jak zauważyli badacze - Mach w samej powieści zamknął niewiarę w powodzenie awangardowego eksperymentu i ogłosił prymat fabuły ${ }^{2}$.

Poetykę narracji Gór nad czarnym morzem analizował ongiś German Ritz, przekonując, że takie a nie inne ich uformowanie ma związek z zaszyfrowaną w utworze Macha opowieścią o pożądaniu homoseksualnym³ ${ }^{3}$ Rozpoznanie Ritza pozostawało jednak lekturą izolowaną. W swojej poprzedniej książce postanowiłem podjąć trop zaproponowany przez szwajcarskiego badacza i obecność tego pragnienia prześledziłem w pozostałych utworach Macha, któremu poświęciłem rozdział Między mężczyznami - proza Wilhelma Macha. Socrealizm psychoanaliza podszyty. Pozostawiłem wówczas zasadniczo na boku powieść Agnieszka, córka Kolumba, uznając, nieco na wyrost, że ostatnia powieść autora Gór rządzi się trochę innymi zasadami niż wyznaczany przez cztery wcześniejsze powieści i opowiadania zrąb jego twórczości. Ambitna awangardowość według słów samego Macha miała bowiem w niej ustąpić miejsca przystępności, łatwości odbioru - Agnieszka stanowić miała odpowiedź na zapotrzebowanie czytelnicze lat sześćdziesiątych - te zaś parametry powieści zdawały się wykluczać obecność „skandalicznej” tematyki

1 W. Maciąg, Literatura Polski Ludowej 1944-1964, Warszawa 1973, s. 429.

2 Zob. A. Fiut, Dowód nietożsamości. Proza Wilhelma Macha, Wrocław 1976, s. 75.

3 G. Ritz, Iwaszkiewicz, Breza, Mach. Niewypowiadalne pożadanie a poetyka narracji, przeł. A. Kopacki [w:] idem, Nić w labiryncie pożądania. Gender i pleć w literaturze polskiej od romantyzmu do postmodernizmu, Warszawa 2002, s. 177-195. 
homoseksualnej ${ }^{4}$ Dziś mam okazję wrócić do Agnieszki i zrewidować nadto powierzchowny sąd, by zastanowić się nad tym, jak pisarz (choć nie awangardowy tout court, to jednak skory do eksperymentów i progresywny nie tylko w wymiarze zainteresowań estetycznych, lecz także w sensie społecznego zaangażowania) przedstawił na kartach tej z zamierzenia popularnej powieści męskość, która - jak starałem się to ukazać w innym artykule - stanowiła jeden z głównych obszarów jego zainteresowań literackich. Wzorce męskości i normatywne przemiany, jakim one podlegają, interesują bowiem Macha jako „temat współczesny” w szerszym kontekście projektu literatury jako uczestniczki „życia społecznego”. Pisarz zdaje się trafnie rozpoznawać problemy społeczeństwa podlegającego $\mathrm{w}$ latach powojennych przyspieszonej modernizacji5:

[...] sprawdzenie rodziny jako formy współżycia; awans społeczny i jego nierównomierne przebiegi jako źródło nowych zjawisk i przeżyć (często konfliktów) moralnych i uczuciowych; s tarzy i młodzi -autentyczność czy pozorność antagonizmu? ${ }^{6}$.

Wykazywałem również, że intencjonalnie pogłębione Machowe przedstawienia męskości i jej przemian (z uprzywilejowaniem relacji ojciec-syn) we wszystkich właściwie powieściach i opowiadaniach naznaczone są dużą dozą czegoś, co chętnie nazwałbym „eksterytorialnym krytycyzmem”. Jego konstytutywnymi cechami są: przekonanie o agresywności jako immanentnej cesze męskiej, jak i wyrażane przekonanie, że ta „agresywna męskość” ma, bądź może mieć, charakter autodestrukcyjny. Jako taka zaś jest toksyczna ${ }^{7}$ i powinna zostać - jako społeczny anachronizm - przezwyciężona w zrewolucjonizowanym przez Polskę Ludową układzie społecznym. Pozwolę sobie na krótki autocytat:

4 O zamiarach twórczych towarzyszących powstaniu Agnieszki pisze Mach w posłowiu do powieści: W. Mach, Agnieszka, córka Kolumba, Warszawa 1965, s. 375. Kolejne cytaty z powieści oznaczam skrótem ACK i odesłaniem do odpowiedniej strony.

5 Szeroko pisze o nich Przemysław Czapliński w szkicu Resztki tradycji. Sarmatyzm, uwtaszczenie ciat i późna nowoczesność [w:] idem, Resztki nowoczesności. Dwa studia o literaturze i życiu, Kraków 2011, s. 15-146. O konflikcie pokoleń zaś: M. Czerwiński, Przemiany obyczaju, wyd. II, Warszawa 1972, s. 121-126.

${ }^{6}$ W. Mach, O temacie wspótczesnym [w:] idem, Szkice literackie, t. II: W Polsce $i$ w świecie, Warszawa 1971, s. 384.

7 Pojęcie toxic masculinity pojawia się często w naukach społecznych i psychologii na oznaczenie konstelacji społecznie regresywnych cech męskich służących wzmacnianiu męskiej dominacji, wyrażających się m.in. przez poniżanie kobiet, zachowania homofobiczne, nadmierną agresywność. 
Gdyby szukać jakichś punktów wspólnych między tymi postaciami mężczyzn auto- i destrukcyjnych należałoby wskazać, że wszystkich ich (a także innych tu nieomawianych) spotyka klęska, ich sprawa przegrywa. Wszyscy oni bowiem u Macha reprezentują wartości anachroniczne, dla żadnego z nich nie będzie miejsca w nowym porządku świata: chałupa Jawora się wali, a on sam prawdopodobnie próbuje popełnić samobójstwo (fabuła nie jest tu jasna), Zenon Bałcz z Agnieszki odchodzi, Andrzej Osiecki wraz z ojcem są tytułową „rdzą”... Zanim jednak ci i inni mężczyźni - odejdą, zniszczą relacje rodzinne ${ }^{8}$.

\section{Ponieważ}

[...] właściwie każda rodzina opisywana przez Macha jest kłębowiskiem żmij, w środku którego znajduje się zaburzona relacja ojciec - syn. Deklaracja padająca w debiutanckiej Rdzy z ust młodego bohatera „Nienawidzę tatusia” stanowi punkt wyjściowy zaskakująco wielu fabuł Macha' ${ }^{9}$.

Jednocześnie jednak, analizując wcześniejsze utwory Macha, zauważyłem, że relacje między mężczyznami są w prozie pisarza często nacechowane ambiwalencją - przemoc, siła i dominacja nierzadko mają nieskrywany charakter erotyczny, są cechami (nieco przewrotnie) pociągającymi. Męska agresja, dominacja, przemocowość ukazywane są jednocześnie jako atrakcyjne i odpychające, fascynujące i godne potępienia, afirmowane i budzące lęk. Być może to właśnie ten naddatek znaczeniowy sprawia, że Mach do obficie wówczas owocującej literatury „małego realizmu” ma stosunek nader krytyczny, a o powieści, która jest tematem tego artykułu, powie wręcz, że powstała z ,mimowolnej, odruchowej przekory” wobec tego dominującego w latach sześćdziesiątych nurtu produkcji literackiej, której bohaterowie są nadto jednopłaszczyznowi ${ }^{10}$. Homoseksualność Macha nie stanowiła tajemnicy w środowisku pisarskim. Współcześnie jest jednym z bohaterów Homobiografii Krzysztofa Tomasika ${ }^{11}$. W żadnym jednak utworze - poza być może Którąś Brama i przynajmniej częściowo Górami nad czarnym morzem -

${ }^{8}$ W. Śmieja, Homoseksualność i polska nowoczesność. Szkice o teorii, historii i literaturze, Katowice 2015, s. 397.

9 Ibidem, s. 397-398.

${ }_{10}$ Zob. W. Mach, Szkice krytyczne..., s. 423.

${ }^{11}$ K. Tomasik, Homobiografie, wyd. II zm. i poszerz., Warszawa 2014, s. 343-364. Biograf zwraca uwagę na obecność oficjalnego nurtu wspominania pisarza i interpretowania jego dzieła (książki Fryciego, Poradeckiego, Fiuta), jak i nurt drugi, „mniej jednorodny, rozproszony, bez wzajemnych odniesień, ale układający się w jedną, bardzo spójną opowieść" (s. 344). Chodzi Tomasikowi o zapisy pamiętnikarskie przyjaciół pisarza: Kazimierza Brandysa, Kazimierza Wyki, Marka Nowakowskiego, Tadeusza Konwickiego. Wszyscy oni wspominają zdziwienie homoseksualnością pisarza, z ich wspomnień „wyłania się dramat samotności, źle lokowanych uczuć, przymus ukrywania się i poniżenie z tym związane" (s. 344). Warto zauważyć, że wydana ostatnio przez Gminne Centrum Kultury 
problem homoseksualnej relacji nie jest stawiany w centrum ani nawet na marginesie pisarskiego (a także eseistycznego czy felietonowego) zainteresowania. Podobnie za to jak w przypadku twórczości Jerzego Andrzejewskiego $^{12}$, u Macha mamy do czynienia ze swoistym „spojrzeniem z ukosa” na hegemoniczne, normatywne doksy dominujących wzorców męskości: zainteresowanie Macha niejednoznacznymi i skomplikowanymi relacjami, hierarchiami i emocjami wiążącymi mężczyzn między sobą jest dla czytelnika tej prozy ewidentne. Nie inaczej jest w Agnieszce, która w ten sposób objawia się nie tyle jako zaskakująca (według Aleksandra Fiuta powieść „,była dla wszystkich zaskoczeniem"13), ile jako kontynuująca obecne we wcześniejszej twórczości Macha wątki, przede wszystkim zaś te, które wiążą się z refleksją nad męskością i mężczyznami. Innymi słowy, można wyrazić przypuszczenie, że koncentracja pisarza na męskości i specyficzny sposób postrzegania „ról męskich" w większości jego utworów wiążą się z nieheteronormatywną sytuacją biograficzną pisarza; sytuacją, która sprzyjała spoglądaniu na dominujące modele męskich zachowań „,z ukosa”, queerowemu spojrzeniu - powiedzielibyśmy dziś.

Krytycy często w omowny sposób próbowali ujmować także osobność i osobliwość stylu Macha. Częstokroć opis postawy twórczej, stylu, predylekcji tematycznych wiązany był z dość powszechną wiedzą o płciowej nienormatywności autora. Przegląd figur tego języka zaproponowałem w innym miejscu ${ }^{14}$, tu pozwolę sobie tylko na jeden przykład zaczerpnięty z leksykonu literatury pierwszego dwudziestolecia PRL autorstwa W. Maciąga:

Mach jest bowiem pisarzem o wyraźnie ukształtowanym języku, którego właściwością jest niechęć do dosadności, do „krzepy”, do jaskrawej, brutalnej zmysłowości. Jest to język ,„pośredni” niejako, nazywający świat z ostrożną, „nieśmiałą" tkliwością, język kunsztownej aluzji, język elipsy i peryfrazy przekształconej w zdanie poboczne ${ }^{15}$.

i Sportu w Ostrowie z/s w Kamionce broszura poświęcona pamięci Macha zupełnie pomija ten „niewygodny” aspekt jego biografii (A. Bal, Wilhelm Mach. Pisarz z Kamionki, Kamionka 2016).

12 O „eks-centrycznej” perspektywie Jerzego Andrzejewskiego pisałem w Homoseksualności i polskiej nowoczesności. Podobny, pogłębiony względem literatury tzw. szyderców, eks-centryzm charakteryzuje w latach sześćdziesiątych pozycję piszącej kobiety (np. Maria Kuncewiczowa w Tristanie 1946) czy emigranta (Michał Choromański w powieści Dygresje na temat kaloszy). W każdej z tych realizacji męskość jest konstruktem podejrzanym, toksycznym.

13 A. Fiut, op.cit., s. 127.

14 Analizowałem ten język: Homoseksualność i polska nowoczesność..., s. 379-383.

15 W. Maciąg, op.cit., s. 427. 
W Agnieszce... nie jest inaczej, warto się jednak przyjrzeć tej, mimo pozornej prostoty, zaskakująco niejednoznacznej powieści ${ }^{16} \mathrm{w}$ kontekście nie tylko pozostałej twórczości Macha, lecz także w odniesieniu do specyfiki czasów, w jakich powstawała.

Prądy kulturowe, społeczne i umysłowe, które z całą siłą wybuchają na Zachodzie, dotyczą także PRL, lecz ich forma jest inna, stłumiona, okrojona, cenzuralnie kastrowana, kontekstowo deformowana. Wydaje się zatem, że i owo fundamentalne przesunięcie w kulturze Zachodu, w ramach którego załamują się w latach sześćdziesiątych tradycyjne ideały męskości ${ }^{17}$, w PRL przybiera bardzo swoisty wymiar, którego najbardziej wyrazistym przejawem jest tzw. spór o bohaterszczyznę, o którym Przemysław Czapliński pisze następująco:

Przewlekły spór o bohaterszczyznę jaki wybuchał i gasł w tamtym okresie, dotyczył stosunku do heroicznej przeszłości. Szydercy, kpiarze, ironiści - Różewicz, Grochowiak, Iredyński, Munk, Wajda, Mrożek - odsłaniali śmieszność patetycznych gestów, okrucieństwo retoryki wymuszającej heroiczne zachowania na Polakach [...] Nie atakowali tradycji, lecz użytek, jaki z niej zawsze można uczynić. ${ }^{18}$

\section{A konserwatywny Dariusz Gawin dodawał:}

Walka z bohaterszczyzną, jaką toczyli „szydercy” w latach sześćdziesiątych, była toczona w przestrzeni oficjalnej i z tego też powodu jej ramy wyznaczała cenzura. Stąd cała dwuznaczność sporu toczonego z komunistycznym nacjonalizmem w wydaniu „partyzantów” - zawłaszczenie przez ludzi Moczara patriotycznej retoryki doprowadziło do dziwacznej sytuacji, w której jedną z najefektywniejszych form antykomunizmu wydawała się walka $\mathrm{z}$ tradycją narodową (pisał o tym przed laty Andrzej Werner w książce Polskie, arcypolskie $)^{19}$.

Twórczość szyderców, choć popularna, ma charakter kontestatorski i wyzywający. Zbigniew Załuski, lecz także tacy pisarze, jak Janusz Przymanowski, Jan Gerhard, Wojciech Żukrowski, Andrzej Brycht (i - przy założeniu, że

16 Autor monografii o twórczości Macha, Aleksander Fiut, przestrzega, że „w trakcie analizy tej pozornie łatwej powieści należy zachowywać daleko posuniętą ostrożność. Autor bowiem mnoży paradoksy, zastawia pułapki, rozbija utarte schematy". A. Fiut, op.cit., s. 128.

17 Zob. np. J.-J. Courtine, Introduction. Impossible virilité [w:] Histoire de la virilité, vol. III: La virilité en crise? XXe - XXIe siècle, sous la direction de J.-J. Courtine, Paris 2011, s. 9-11.

18 P. Czapliński, PRL i sarmatyzm [w:] (Nie)ciekawa epoka. Literatura i PRL, red. H. Gosk, Warszawa 2008, s. 168.

19 D. Gawin, Krytyczny patriotyzm. Próba bilansu, http://www.omp.org.pl/artykul. php?artykul=82 [dostęp: 21.11.2017]. 
nazwisko na okładce książki wskazuje istotnie jej autora - Mieczysław Moczar) reprezentują w owym sporze tendencję heroizacyjną, broniącą tradycyjnej wizji kultury, która - paradoksalnie - ma znajdować swoje przedłużenie w rzeczywistości społeczno-politycznej PRL, natomiast „szydercy”, których twórczość ustabilizowała się po latach jako kanon narodowej kultury i literatury $\mathrm{XX}$ stulecia, stoją na stanowiskach kontestacji, buntu, niezgody, zmiany ${ }^{20}$. Gorące publicystyczne dyskusje między obiema stronami sporu wybuchały przy okazji głośnych premier filmowych (np. filmów Andrzeja Wajdy) czy książek (Sennik współczesny Tadeusza Konwickiego, Pamiętnik z powstania warszawskiego Mirona Białoszewskiego). Agnieszka i powstający równolegle z powieścią film Agnieszka '46 Sylwestra Chęcińskiego z Leonem Niemczykiem w głównej roli męskiej właśnie w ten spór się wpisują, co więcej - choć dziś powieść pozostaje w zapomnieniu, to à l’epoque stanowiła jeden z najgorętszych momentów debaty. Napastliwy szkic przeciw filmowi Chęcińskiego według scenariusza Macha pt. Twój brat - zbir napisał Zbigniew Załuski. Szczególną niechęć recenzenta budzi główna i tytułowa bohaterka Agnieszka Żwaniec - „naiwna” nauczycielka, rozbijająca męskocentryczną, żołnierską wspólnotę:

Jako remedium na zdziczenie ,zbrukanych wojną” ofiarowano nam Agnieszkę jako taką. I właśnie dlatego, a nie na skutek przeoczenia, jest ona tak idealnie wyizolowana z życia, z tak niedawnej przeszłości, z przeżyć i doświadczeń narodu. Właśnie dlatego nie ma życiorysu. Bo zastanówmy się. Gdzie się uchował ten czyścioszek, ta naiwniaczka [...], ten słodki, promienisty anioł dobroci? Ile Agnieszka ma lat? Osiemnaście - dziewiętnaście? Jest rok 1946, a więc gdy wojna się zaczęła - miała trzynaście, gdy się skończyła - siedemnaście. Niczego nie widziała? Nie przeżyła sama? Skąd się więc ona wzięła? [...] Agnieszka jakby spadła z księżyca - i właśnie o to chodzi. Chodzi o przeciwstawienie złu - zwykłych ludzi, a więc siłom, które dotąd tworzyły historię - ludzi i sił nowych, czystych, niczym nie zbrukanych ${ }^{21}$.

Społeczny wymiar konfliktu pokoleniowego, na który nakłada się baśniowy konflikt dobra ze $z^{2} \mathrm{em}^{22}$, ma jeszcze mocniejszy niż w filmie charakter

20 Pierwsza była, stosując formułę Michała Głowińskiego, ,literaturą w PRL”, a druga „literaturą PRL”. Zob. M. Głowiński, Jak pisać o Polsce Ludowej? [w:] Opowiedzieć PRL, red. K. Chmielewska, G. Wołowiec, Warszawa 2011, s. 9-15.

${ }_{21}$ Z. Załuski, Twój brat-zbir [w:] idem, Siedem polskich grzechów głównych. Nieśmieszne igraszki, wyd. V, Warszawa 1973, s. 423.

22 „To zło to komendant Bałcz, to jego osadnicza wioska, to te żołnierskie mundury, ordery, wspominki i cmentarze, apele poległych. To wszystko jest zbyt konkretne jak na baśn o archaniele Michale, strącającym potępione chóry Belzebuba. To realny kompleks kombatanta, człowieka w żołnierskim drelichu z Odznaką Grunwaldzką, znaczkiem 1. Dywizji Kościuszkowskiej na kieszeni z baretkami odznaczeń, które - dowodząc udziału w wojnie - stanowią jakby krosty, znamię choroby" (ibidem, s. 425). 
w powieści, której akcja toczy się najprawdopodobniej po roku 1955, a więc powieściowa Agnieszka jest dzieckiem czasów powojennych, cały zaś świat przedstawiony Chrobrzyczek i zamieszkującej je społeczności staje się jeszcze bardziej odrealniony, bardziej groteskowy. Usytuowanie akcji powieści u progu epoki „małej stabilizacji” pozwala na przedstawienie Agnieszki jako dziecka Polski Ludowej tout court (nie ma ona rodziny naturalnej i jest wychowanką instytucji opiekuńczych, siłą więc rzeczy nie ma ona także niemal zawsze u Macha „toksycznego” ojca). Agnieszka jest nie tylko - jak chciało wielu recenzentów - współczesną Siłaczką, ale i autentyczną emancypantką: jest samodzielna, wysportowana (uprawia dżudo), czego nie mogą jej wybaczyć mieszkające w Chrobrzyczkach kobiety - żony i partnerki byłych podkomendnych Bałcza. W ich oczach Agnieszka zagraża, jakby dziś powiedziano „naturalnemu porządkowi płci”: „,...] w chłopskich portkach lata, z chłopami się siłuje [...], nowych sobie sprowadza - co oni w niej widzą, sucha, koścista, ubrać się nie potrafi..." (ACK 98).

Związany z frakcją moczarowską pułkownik recenzent identyfikuje jeszcze jeden wymiar konfliktu - konflikt polityczny. Powstałe na XX-lecie PRL powieść Macha (nagrodzona Nagrodą Państwową II stopnia, tłumaczenia na 8 języków) i film Chęcińskiego w tej perspektywie okazują się elementami ważnej rozgrywki politycznej, mającej ograniczać wpływy kombatantów, a walor ideowy nagrodzonej powieści realizuje polityczne wytyczne (krytycy sugerowali nawet, że powieść należy do nurtu rozrachunku ze stalinizmem) ${ }^{23}$ :

To przecież właśnie między dwudziestoleciem PRL a dwudziestoleciem zwycięstwa przypomina nam Agnieszka, że od patosu do histerii niedaleko, a od histerii do śmieszności jeden krok. To przecież teraz pokazano nam ten film [chodzi o filmową wersję Agnieszki - W.Ś.] wołający jednoznacznie, żeby przestać bębnić na cmentarzach, i wskazujący, że ten, co bębni i „,szarogęsi” się w imię tego bębnienia, ten „komendant”, człowiek silnej ręki, musi odejść. Bo nawet, choć jest trochę sympatyczny, nie nadaje się do współpracy z normalnymi, zdrowymi ludźmi, bo nawet gdy chce poskromić chamstwo, to potrafi tylko chamskimi metodami, metodą ,mocnego uderzenia" ${ }^{\prime 24}$.

Cokolwiek by powiedzieć, polemika Załuskiego, jakkolwiek inteligenta, pozostaje zupełnie nieczuła na wieloznaczność i polifoniczność tej zapomnianej dziś z kretesem powieści równie zapomnianego pisarza. Współczesna lektura i współczesne języki interpretacji otwierają zupełnie inną perspektywę lekturową.

Najwyższa chyba pora pokrótce przedstawić fabułę Agnieszki. Miejscem akcji jest odcięta od świata, położona pośród jezior i mokradeł wieś Chro-

23 J. Poradecki, Pisarstwo Wilhelma Macha, Łódź 1984, s. 194.

24 Z. Załuski, op.cit., s. 426. 
brzyczki. W kilkanaście lat po wojnie rządzi w niej sołtys Zenon Bałcz ${ }^{25}$. Rządzi swoją wsią niczym jakiś wojenny watażka, samozwańczy hetman i dyktator, który za nic ma sobie cywilne władze centralne. Korzysta z oddalenia wsi od głównych szlaków komunikacyjnych i położenia wśród bagien. Mężczyźni, dawni podkomendni Bałcza, rządzą wsią i wytwarzają autarkiczną, ekskluzywną wspólnotę, której spoiwem jest bimber. Stanowi on podstawę kontaktów towarzyskich, ale też sprzedawany do okolicznych wsi jest źródłem utrzymania chrobrzyczan. Nie trzeba dodawać, że łamanie monopolu spirytusowego jest przestępstwem, znakiem anarchizmu żołnierskiej wspólnoty (czy dziś mówilibyśmy o niej jako o wspólnocie ,żołnierzy wyklętych”?). Zmaga się z Bałczem - ale i ulega jego magii - Agnieszka Żwaniec, nauczycielka, wysłana tu dla zorganizowania szkoły delegatka ,z centrali”. Konflikt romansowy (albo też romans konfliktowy) między tym dwojgiem jest motorem intrygi powieściowej. Narracja, preferująca formy mowy pozornie zależnej i bliska tytułowej bohaterce, umożliwia prezentowanie Bałcza w taki sposób, w jaki jawi się on w świadomości kobiecej protagonistki. Opis ten, uważny, detaliczny, prowadzi od początkowej niechęci nie tylko ku dość infantylnej apoteozie, którą uprawomocnia naiwność bohaterki, ale staje się także coraz bardziej erotyczny, wyraźnie uprzywilejowując cielesność:

To wstrętnie, wstrętnie chodzić tak ze sznurem owiniętym na ramieniu. Hycel. Kowboj. Pyszałek. Zarozumialec. [...] Nigdy go nie nazwie po imieniu, nawet w myśli. To imię jest prostackie i pretensjonalne, jak on sam. Ale i o nazwisku wolałaby zapomnieć, nigdy go nie znać, nie wymawiać. Niegodziwe, śmieszne, zuchwałe nazwisko, jak on sam. Cyrkowe sztuczki ze sznurem. Gdzie i jak się ich nauczył? Gdyby się z nim mocowała, rozłożyłaby go na łopatki. I biłaby go, biła kułakami, ach, nie po głowie [...], biłaby go po mocnym, sklepionym torsie, po mocnych i stromych barkach [...] (ACK, 144).

To jest Zenon Bałcz. Ta głowa odsłonięta, zwięzła, szorstka w rysunku, jakby wyłoniona z sześciennej twardej bryły niepełnym złagodzeniem płaszczyzn i wyokrągleniem krawędzi. Te włosy krótkie, spoiste, ciemniejsze teraz na tle śniegu

25 W nazwisku odnajdujemy aluzję literacką do Kadenowskiego generała Barcza. Mach, tworząc tę polifoniczną powieść, zadbał, by inteligencki czytelnik odnajdywał związki powieści z tradycją literacką, ale ważniejsze jest to, że początek historii Bałcza wiąże się z edukacją sanacyjną. Do dziś przechowuje swój ryngraf, szablę. Opowiada o tym Agnieszce: „Śmieszna menażeria. Wzory, pozory, honory. Farbowana ruina, głodne apetyty. Tam brałem pierwsze lekcje. W górze Bóg i ojczyzna, w dole ciemny plebs, a w środku ja, kandydat na bohatera. Pokusa ciągnęła w górę, a siła ciężkości w dół. Rozstrzygnęła historia [...]" (ACK, 195). Komendanta Bałcza trudno więc wpisać w jednoznaczne ramy polityczne. Choć Mach od pewnej dozy polityczności w powieści się nie uchyla, nie jest to polityczność znana z literatury socrealizmu. Wydaje się, że tym, co ważniejsze od polityki, jest artystyczne ujęcie pewnej formuły męskości i męskich zachowań, które postrzegane są jako rezultat edukacji wojennej - polityczną stawką powieści wydaje się przezwyciężenie ich anachronizmu i włączenie w obręb od nowa skonstruowanej wspólnoty, tej zaś gwarantką jest Polska Ludowa. 
niż są rzeczywiście. Kark mocno osadzony, szeroki, nad śmiałym łukiem ramion. Barczystość nieociężała, gladiatorski impet postaci smukły zarazem i gibki, siła olbrzymia stonowana wyrazem leniwego znużenia - przeciwieństwa cech w tym obrazie nie przeczą sobie, składają się harmonijnie, groźnie i nieodparcie, jawnie już dla Agnieszki uroczo w przymus zapatrzenia, w przymus nazywania swojego zachwytu (ACK, 243).

Półwojskowa kurtka Bałcza nie stanie się królewskim płaszczem. Kryje w sobie tors śniady, gładki, obcy. Tam drzemie dzikość, gwałtowność, okrucieństwo, a także oddech dla głosu porywczego, gniewnego, dla słów drwiących i prostackich. [...] Więc co mnie pociąga w tym człowieku? Ta straszna obcość. Tak. Obcość (ACK, 259).

Dzika, redundantna rzec można, męskość paradującego z nieodłączną liną na ramieniu (czym Bałcz przypomina Indianę Jonesa!), ma swoisty seksapil, na którym koncentruje się narracyjne spojrzenie. Bezlitośnie krytykujący powieść Załuski doszukuje się w (filmowym) Bałczu realistycznego portretu berlingowca, ale przecież portret tego bohatera nie jest realistyczny (to raczej skupiona wiązka fantazmatów męskich o sile wyrazu wzmocnionej przez posiadanie „superbohaterskich” rekwizytów, jak to nieodłączne lasso właśnie), on sam zaś tak mocno wyrasta ponad wspólnotę, której przewodzi, że nie można abstrahować od pewnej mityczności czy może archetypiczności w kreacji tej postaci. Powieść Macha beznadziejnie rozpięta między gatunkami, stylami i wzorcami „wysokimi” (psychologizm, literatura pozytywizmu, poczucie odpowiadania na „zamówienie społeczne”) a „niskimi” (sensacyjność, wzorce powieści przygodowej, romansowość) opisywana bywa także w kategorii komiksowości o „ekspresji typowej dla komiksu” wspomina np. Jerzy Poradecki ${ }^{26}$. W odniesieniu do powieściowej konstrukcji postaci Bałcza można również postawić tę kwestię: w jakim stopniu to bohater w gruncie rzeczy komiksowy i przerysowany?

Ta proweniencja postaci, przemilczana w autorskich komentarzach, jest całkiem prawdopodobna. Wszak w 1961 roku Mach odbył czteromiesięczną podróż do USA. Jakkolwiek tamtejszy styl życia i kultura nie przypadły mu do gustu, to jednak tak długi pobyt mógł być okazją do poznania komiksowych superbohaterów i spożytkowania tej znajomości w komponowaniu fabularnych wątków Agnieszki. Inny trop może prowadzić do popularnych w przedgejowskiej kulturze amerykańskiej magazynów kulturystycznych. Jak zapewnia Kenneth R. Dutton, w USA w owym okresie popularne były, prócz samych magazynów kulturystycznych, ,artystyczne”, wzorowane na antycznych rzeźbach akty Alonzo „Lona” Hannagana (można je było nabywać jako postery, pocztówki etc.). Tego typu wizerunki podkreślały atletyczność budowy, siłę fizyczną, masywność, ale sugerowały też często homoerotyzm i bliskość cielesną między mężczyznami, np. w pozowanych sytuacjach walki,

26 J. Poradecki, op.cit., s. 188. 
zmagania $^{27}$. W świetle analizy powieści, źródeł, komentarzy autorskich nie da się chyba odpowiedzieć na wyżej postawione pytanie jednoznacznie, choć jak będę przekonywał w dalszej części tego szkicu - skłonny jestem uznać (m.in. za A. Fiutem), że Bałcz jest jednak postacią „,serio” i ucieleśnia (fakt, że w pewnym powiększeniu) cechy „męskie” bohaterów wcześniejszych powieści Macha.

Erotyczna fascynacja Agnieszki to ,zew płci”, przeciw któremu buntuje się jej świadomość. Pociąga ją cielesność mężczyzny i owa wyobrażona archetypiczna ponadczasowa „męskość”. Społeczny habitus Bałcza, w którym pociągająca męska siła przechodzi niepostrzeżenie w brutalność, konkretyzuje się jako przewodnictwo w bimbrowniczej szajce i stanowi już większy problem - Agnieszka podejmuje walkę z sobą i z Bałczem. Ów chwyt, w którym mamy do czynienia z podwójnym widzeniem bohatera, raz w kategoriach mityczno-baśniowych, a kontrapunktowo - w realistycznej skali, w której spojrzenie mityczne ulega deprecjacji, nie jest chwytem nowym. Owa podwójność stanowi dominantę kompozycyjną we wcześniejszej powieści Macha Życie małe $i$ duże, w której dziecięca perspektywa opisu postaci ojca dopełniana jest przez korygującą ją i deheroizującą ojca perspektywę dorosłego narrato$\mathrm{ra}^{28}$. W Agnieszce problem podmiotu patrzącego jest nieco bardziej złożony: narracja usytuowana jest tak, by odzwierciedlać świat takim, jaki się on jawi oczom bohaterki; nie jest w tym jednak w pełni konsekwentna, bo spojrzenie „przechwytywane jest” przez trzecioosobowego „obiektywizującego” narratora. Jego oscylacyjność wprowadza stan nieokreśloności, zmuszając tym samym czytelnika już to do akceptacji oferowanej wizji świata (jeśli akurat jawi się ona jako mimetyczna), już to do traktowania jej z nieufnością (kiedy staje się groteskowa, mityczna, subiektywna).

Agnieszka, reprezentująca według Załuskiego „ludzi nowych, czystych, niczym niezbrukanych", zaburza konserwatywne normy płciowe obowiązujące w Chrobrzyczkach, gdzie kobiety podporządkowane są zasadniczo męskiej wspólnocie, a ich aktywność społeczna poddana jest ścisłej reglamentacji - za właściwą uchodzi pełna uległość i ścisła separacja sfer męskich i kobiecych ${ }^{29}$. Agnieszka jest inna - nie tylko nosi spodnie, za pomocą dżudo obezwładnia mężczyzn, a jej wysportowane ciało nie ma w sobie „kobiecych krągłości”, ale także - ku zdziwieniu i zgorszeniu mieszkanek wsi - potrafi stawić czoła „Komendantowi”, stanąć z nim jak równa z równym. Taka równorzędna relacja, jakkolwiek uwłaczająca tradycyjnym płciowym habitusom chrobrzyczan

27 K.R. Dutton, The Perfectible Body: The Western Ideal of Male Physical Development, New York 1995, s. 245-246.

${ }^{28}$ Jerzy Poradecki zauważa, że ,„ṕźny” Mach ,powtarza siebie z pierwszych lat powojennych" (J. Poradecki, op.cit., s. 177).

${ }_{29}$ Niewątpliwie ciekawa byłaby feministyczna rewindykacja lekturowa tej (i nie tylko tej) powieści Macha. 
i chrobrzyczanek, wytwarza swoistą formę „nowego erotyzmu”. Doskonale widać tę ambiwalencję w scenie tańca podczas wiejskiej zabawy, kiedy Agnieszka staje wobec Bałcza do tańca-walki (przez co też zyska jego uznanie):

Szalona polka! Pod naporem coraz szybszej, coraz zawrotniejszej melodii pary odpadają jedna po drugiej. W opustoszałym wreszcie środku sali wirują już tylko Bałcz z Agnieszką. On trzymający ją mocno w pasie, ona przegięta nieco w bok, lotnymi półokręgami nadążająca jego dzikim, wciąż dzikszym obrotom. On nie tknięty znużeniem, przeciwnie, jak gdyby porwany furią taneczną rosnącą nie do powstrzymania, ona zawzięta. To już nie taniec, to walka (ACK, 110).

Przybycie Agnieszki i osobliwa psychomachia, w którą się angażuje, sprawią, że rozpadowi ulegnie cała hierarchiczna męska wspólnota Chrobrzyczek i wynikający z niej ścisły genderowy podział na sfery męską i kobiecą. To walka ideowa, trzeba bowiem powiedzieć, że osobowości i swoistemu czarowi „Komendanta” ulegają podwładni, np. Semen - podkomendny jeszcze z partyzanckich czasów. Historia Semena jest tu dość znamienna. Nie wiadomo, skąd i dlaczego trafił w strony działania oddziału Bałcza, został ranny, Bałcz go odnalazł i potem są, według słów Semena, „zawsze razem”, podczas jednej akcji nawet „trafiło ich obu naraz, od jednego szrapnela”. To specyficzne braterstwo, braterstwo rany, sprawia, że gdy Bałcz po nieudanej akcji zostaje przeniesiony, Semen „sam się podał do raportu, żeby i jego”. Semen, najwierniejszy z wiernych, pod wpływem Agnieszki zaczyna się przeciw Komendantowi buntować, a podczas próby gwałtu na Agnieszce, jakiej dopuszcza się, chcący wziąć ją siłą, Bałcz, Semen - odpychając sołtysa - ratuje nauczycielkę (ACK, 256).

Sadystyczne zachowania i despotyzm Bałcza mają uzasadnienie w jego przeżyciach wojennych. Kiedy mieszkańcy Chrobrzyczek i byli podkomendni Bałcza świętują rocznicę pamiętnej bitwy oddziału partyzanckiego z Niemcami, odbywa się kluczowa rozmowa z jednym z zaproszonych gości - majorem. Dawny przyjaciel obnaża zaburzoną, zarażoną wojną kondycję Bałcza (Załuski opisuje ją jako „kompleks kombatancki” ${ }^{30}$ ) i uświadamia mu, że jego działanie jest destrukcyjne, wprowadzony dryl nieskuteczny i wysilony, a postawa fałszywa (ACK, 333-334). Wspólnota zorganizowana przez Bałcza jest wspólnotą ufundowaną na przeszłości, na kulcie śmierci. To wspólnota grobów. Znaki tego ciemnego kultu rozsiane są w całej powieści (śmiercią i cierpieniem zarażane są we wsi nawet dzieci dręczące zwierzęta domowe, ACK, 57), ale expressis verbis nazywa je Bałcz podczas przemówienia w rocznicę bitwy jego oddziału:

30 W dyskusji nad kompleksem kombatanckim biorą udział S. Grzelecki (Ostatni kombatant, „Życie Warszawy” 1964, nr 284; K. Koźniewski, Rozmowa! O czym?, „Polityka” 1964, nr 41; K.T. Toeplitz, Agnieszka '46, „Świat” 1964, nr 50. 
[...] jak w każdy marzec tego dnia, w rocznicę, oddajemy wam honor, koledzy. Honor należny, boście najlepsi z nas. Ci, co polegli, zawsze najlepsi, lepsi od żywych. Śmierć to najwyższy i najpewniejszy awans, a życie to zawsze degradacja. Różnie tu nam się wiodło, żywym, przez czas od naszego rozstania, nieraz było chłodno i głodno, aleśmy nie płakali, zgoda była i jedność, był porządek... (ACK, 324)

Ów kult (notabene mocno załgany, gdyż Bałcz dowodzi karną kompanią, a na wojnie granica między zbrodnią a bohaterstwem jest niezwykle cienka) jako ideologiczne spoiwo wspólnoty ceniącej sobie nade wszystko ,jedność i porządek" - daje się opisywać w kategoriach, jakie do opisu protofaszystowskiej wyobraźni freikorpsowców zostały użyte przez Klausa Theweleita. Odwołanie do niemieckiego badacza i jego rozważań pozwoli nam dostrzec, że drużyna Bałcza ucieleśnia ponadhistoryczną formację mężczyzn zarażonych wojną, niezdolnych do życia poza nią:

Ludzkie procesy produkcji zasadniczo wprowadzają życie do swego przedmiotu zwraca uwagę Theweleit. - W przypadku rzemieślnika żywa praca czyni z drzewa stół, w przypadku robotnika - narzędzie z niepoddanego obróbce metalu; żywa praca matki pozwala noworodkowi stać się człowiekiem. Tymczasem w przypadku owych mężczyzn produkcja polega na czymś odwrotnym. Wywołuje ona niejako wojnę przeciw wszelkim społecznym wytworom, zarówno ludziom, jak i przedmiotom, wprowadzanemu w nie życiu. Ich sposób produkcji to przemiana żywego w martwe, rozbiórka życia. [...]

Wydaje się, że właściwy faszyzmowi monumentalizm można rozumieć jako mechanizm obrony przed niepokojącą wielorakością tego, co żywe. Mężczyźni ci czują się tym bezpieczniej, im bardziej rzeczywistość jawi się jako martwa, uporządkowana, monumentalna. Niebezpieczeństwo tkwi w samej żywotności ${ }^{31}$.

Rozmowa, bunty podwładnych, konflikty z okolicznymi wsiami, obecność Agnieszki wprowadzającej nowy - pokojowy - porządek sprawiają, że Bałcz musi stoczyć własną walkę wewnętrzną: targa nim sprzeczność między wojskową, męskocentryczną, kombatancką drużyną (w powieści przedstawianą jednoznacznie groteskowo i krytycznie, co najlepiej widać w scenie z inwalidami wojennymi wzajem przykręcającymi sobie protezami protezy, ACK 52), której komenderuje, a pożądaniem Agnieszki i tego, co ona sobą reprezentuje, a reprezentuje odzyskanie wiary w przyszłość, odtworzenie nadziei:

Dziewczyno, co ty ze mną wyprawiasz. Gdyby nie ty... Nigdy żadnych nie miałem wątpliwości. Gwiżdżę na abstrakcje. A ty mnie zmuszasz, żebym grał w ciemno. Żebym wierzył w coś, czego nie ma, co jest niemożliwe. O czym w ogóle nie

31 K. Theweleit, Męskie fantazje, przeł. M. Falkowski, M. Herer, przekład przejrzał A. Żychliński, Warszawa 2015, s. 220, 222. 
wiedziałem. A ty kusisz, że to jest i jest możliwe, i żeby sprawdzić. Nie wierzę! (ACK, 252)

Konflikt wewnętrzny, w który uwikłał się Bałcz po przybyciu Agnieszki, ma znamiona tragicznego i nierozwiązywalnego: Bałcz nie jest gotowy do zdradzenia swoich dla Agnieszki (a wierność jest cechą waloryzowaną pozytywnie, szczególnie gdy chodzi o etos „towarzyszy broni”), ale dostrzega też bezcelowość własnych dalszych działań jako Komendanta i abdykuje. Bałcz nie jest złym człowiekiem, jest człowiekiem zdeprawowanym przez wojnę i bezkompromisową ideowość (Jerzy Poradecki określa go mianem „ideowego maksymalisty”32, którego zasadą działania jest „wszystko albo nic”). Ku osłupieniu części podwładnych sprzymierza się z młodą nauczycielką i razem niszczą bimbrownię (znajdującą się na zamku, który kiedyś oddział Bałcza $\mathrm{z}$ wielkim poświęceniem zdobywał $\mathrm{z}$ rąk hitlerowców - mamy więc do czynienia $z$ drugim zwycięstwem Bałcza). Tym samym Bałcz niejako przekreśla swoją dotychczasową biografię, przezwycięża samego siebie, nie potrafi jednak uwierzyć w obietnicę przyszłości. Na ostatnich stronach powieści widzimy bohatera w scenie zaiste bardzo patetycznej, relacjonowanej przez Agnieszkę w liście do przyjaciółki:

Widzę [...] człowieka w łódce, wyprostowanego nieruchomo, z wiosłem, którym za moment odepchnie się na wodę. On też patrzy na nią, na pewno, bo raptem przesuwa się ze środka pod samą burtę i drobnym gestem dłoni jakby jej wskazał miejsce obok siebie, zachęcił niepewnie czy zaprosił, a może to jednak był tylko znak pożegnania (ACK, 360).

Bałcz musi odejść, bo nie pasuje do nowych czasów, bo jest anachroniczny i „nowe” w końcu musi nadejść, a Chrobrzyczki muszą się zintegrować z resztą kraju. Bałcz zdołał przekreślić przeszłość, jego przyszłość, jeśli jest jakakolwiek, znika z powieściowego pola widzenia. Racje reprezentowane przez Agnieszkę - entuzjastyczną, acz nieco naiwną nauczycielkę - tryumfują. Jednocześnie jednak Agnieszka (ostatnie karty powieści stylizowane są na jej list do przyjaciółki), odnosząc zwycięstwo na niwie społecznej, ma poczucie klęski emocjonalnej. Powieść Macha można rozpatrywać także jako powieść o dojrzewaniu - na początku powieści w imieniu bohaterki mówi narrator („Nazywa się Agnieszka Żwaniec i w tej sekundzie myśli, że tak się oto nazywa", ACK, 7), a ostatnie słowa powieści padają już z jej ust, zdobyte gorzkie doświadczenie uprawomocnia ją w jej podmiotowości:

Jutro rano stanę naprzeciw moich dzieci. Nie wolno im wiedzieć, że nie jestem od nich ani lepsza, ani mądrzejsza, że sama uczę się pierwszych liter [...].

32 J. Poradecki, op.cit., s. 194. Ideowy maksymalizm to cecha męskiego Bałcza, Agnieszka to „pracowita mrówka”, pełna poświęcenia Siłaczka, która nad wielkie idee przedkłada skromną pracę u podstaw (np. obcinanie kołtuna Uli). 
Ja, Agnieszka Żwaniec, nauczycielka.

Niech już przyjdzie rano.

Do rana jeszcze daleko. Cicha i pusta moja izba szkolna. I ciemna. Ledwie widzę przed sobą dwa rzędy cichych, pustych i ciemnych ławek (ACK, 373).

Bohaterka, walcząc o rząd dusz nad Chrobrzyczkami z Bałczem, zdążyła się w nim zakochać, odrzucając przy okazji awanse Stacha, młodego medyka, karierowicza - typa, w jaki obfitują nowe czasy. Jego ofertą - dla Agnieszki nieatrakcyjną - była forma typowej ,małej stabilizacji”.

Pokonanie Bałcza jest jednak zwycięstwem nieco pyrrusowym. Agnieszka czuje pustkę, rozumie, że smak wolności jest gorzki:

Nazywam się Agnieszka Żwaniec. Myślę, staram się myśleć porządnie, bez chaosu. Jestem. Jestem sama. Dziwię się, zamiast krzyczeć, uciekać czy umrzeć. Może to zdrowie zmusza mnie, bym się tak dziwiła, może młodość. Więc już nie jestem młoda, skoro się tego domyślam. Zamiast płakać (ACK, 361).

Powieść, w której męska, żołnierska wspólnota przedstawiana w krytycznym i satyrycznym świetle doświadcza implozji, a jej przywódca jest uerotyzowany w spojrzeniu młodziutkiej i naiwnej nauczycielki, która jednak nad nim triumfuje, niejako z konieczności musi być niespójna wewnętrznie i konstrukcyjnie przełamana. Wyraźnie widać też swoiste rozszczepienie ideowe powieści, w której gest krytyczny wobec, ujmijmy to tak, kombatanckich norm homospołecznych nieustannie rozpraszany jest przez uwznioślenie, heroizację, erotyzację i nadanie rysu tragicznego postaci Bałcza, znajdującej się w centrum tego męskiego uniwersum.

Wielopoziomową antynomiczność powieści dostrzegli badacze. Fiut pisał o zaskoczeniu prostotą, „tradycyjną techniką narracyjną, banalnością tematu, uproszczonym rysunkiem postaci" 33 , choć jednocześnie uważał, że postać Agnieszki ,przypominała pod pewnymi względami bohaterów - pisarzy (tak samo jak oni uczulona była na kłamstwa wewnętrzne)". ${ }^{34}$ Recenzenci pisali o „współczesnej Siłaczce” (tak to ujmował np. Iwaszkiewicz, ale i wielu innych ${ }^{35}$ ), „rozliczeniu kombatanckiego kompleksu”, jeszcze inni uznali, że mamy do czynienia $z$,romansem pseudonimowanym przez historycznoliterackie parantele”, i przypominali wypowiedź Macha: „najchętniej napisałbym powieść par excellence miłosną, ale pod pseudonimem”. Fiut zauważał: „,powieść zatrzymała się w pół drogi między produkcyjniakiem a jego parodią, aluzją literacką a jej współczesną złośliwą transpozycją, baśnią a groteską. Między Siłaczka a Konopielka" "36. Krakowski badacz wyliczał antynomie

\footnotetext{
33 A. Fiut, op.cit., s. 127.

4 Ibidem.

35 Szczegółowo wylicza A. Fiut, op.cit., s. 127.

36 Ibidem, s. 130.
} 
powieści, które dzieli ona $\mathrm{z}$ całą twórczością Macha: dziecięca wrażliwość gorzka wiedza o życiu, tęsknota za moralistyczną utopią - świadomość niemożności jej urzeczywistnienia, poznanie - niepoznanie, samotność - pragnienie zanurzenia się w ludzkiej gromadzie, baśniopisarstwo - realizm, artystyczna prostota - inklinacje do formalnego wyszukania, tradycjonalizm nowatorstwo. „Bardzo upraszczając, antynomiczny świat Macha sprowadzić można do opozycji wrodzonych predyspozycji pisarza oraz rzeczywistości historyczno-społecznej, w której usiłuje się on odnaleźć, ale odnaleźć w pełni się nie potrafi" ${ }^{37}$.

Opis Fiuta doprecyzowuje pewne kwestie, lecz nie jest zanadto odkrywczy, gdyż właściwie powtarza pisarskie dopowiedzenia, których według autora powieść się domaga. W posłowiu Mach stwierdza, że impulsem do jej (a ściślej mówiąc do pierwotnego zamysłu zawartego w opowiadaniu Za kwadrans wiosna) powstania była „sublimacja osobistych motywów psychologicznych, sprawa na wskroś i wyłącznie własna", która jednak w trakcie pracy zmieniła się w coś, co Mach nazywa „powieścią-rozmową” (w opozycji do „powieści-monologu"). Interlokutorami są nauczyciele prowincjonalni, których wspomnienia w tomie wydanym w 1961 roku przez LSW Mach czytał ${ }^{38}$, jak również czytelnicy spotykani podczas „niezliczonych” wieczorów autorskich. Głównym z nich wnioskiem był ,apel o książkę współczesną w temacie, przystępną w formie, popularną, bez nadmiernego trudu czytelną" (ACK, 375).

W jednej z wypowiedzi recenzenckich zawarł Mach swoje wyobrażenia o współczesnej powieści idealnej ${ }^{39}$, która łączyłaby w sobie antynomiczne spojrzenia. To:

Powieść po męsku zamaszysta w zabudowie panoramy epickiej - i po kobiecemu czuła, wrażliwa i skrzętna w utrwalaniu zmiennej, przelotnej urody drobnych rzeczy, małych chwil, różnych wyglądów i nastrojów, różnych pogód i miejsc.

Agnieszka jest powieścią-rozmową w wymiarze założonej przez pisarza (i potwierdzonej państwową nagrodą) społecznej ważności i pozornie przystępnej formy, ale jest też - z tych samych względów - powieścią „męską” w powyższym rozumieniu jej epickiego wymiaru. To wymiar dominujący: „Opowieść o Agnieszce jest książką-rozmową" (ACK 375), powiada sam pisarz w autokomentarzu. A jednak, jeśli uwierzyć pisarzowi, „męska” powieść-

37 Ibidem, s. 130.

38 Takie będa Rzeczpospolite. Wspomnienia $i$ wypowiedzi nauczycieli, oprac. i wstęp J. Szczawiej, Warszawa 1962.

39 Rozważania na marginesie recenzji powieści Marii Klimas-Błahutowej pt. Siedem krów tlustych przytaczane przez J. Poradeckiego, op.cit., s. 180. 
-rozmowa jest estetycznie niedoskonała, uzupełnić ją musi perspektywa nazywana przez niego kobiecą, bardziej liryczna, introspekcyjna, emocjonalna, wrażliwa na detal, drobiazg, nastrój.

Pozwolę sobie wyrazić przypuszczenie, że w Agnieszce obecność tej perspektywy zapewnia postać głównej, tytułowej bohaterki i ukształtowanie narracji (dominacja mowy pozornie zależnej). Perspektywa kobieca taka, jak ją sobie wyobraża i jak ją konstruuje Mach, obecna jest także na kartach powieści w działaniach bohaterki, jej opiekuńczości wobec słabszych, czułości (ważnym bohaterem jest piesek Agnieszki - Floks, darzony przez nią gorącym uczuciem), estetyzacji (słabość do kwiatów), ale przede wszystkim w uprzywilejowaniu „kobiecego spojrzenia”: to Agnieszka patrzy na Bałcza, to jego ciało jest erotyczne, to o jej emocjach towarzyszących spotkaniom dowiaduje się czytelnik najwięcej (sceny zbliżenia z Bałczem w tańcu, wizyta bohaterki w mieszkaniu Bałcza). Jedną z takich scen jest opowiadana z perspektywy Agnieszki próba gwałtu, jakiej dopuszcza się sołtys Bałcz:

Zamroczona nim, wypukłą żyłą na jego czole, złą czułością w oczach. Jaskrawe od żalu, że tak ginie jej wypiękniała w czekaniu nadzieja. Obalił ją, przygniótł do śniegu rozkrzyżowane ręce. Jego szorstkie usta na jej szyi, na policzku, w kąciku warg. Sprężyła się całym ciałem. Umknęła nieco spod ucisku jego piersi. Skręca głowę w bok. [...] Znów dosięga jej głowy ta twarz zawzięta. Oczy na wpół zakryte powiekami. [...] Obrzmiała różowość warg, błysk zębów:

- Puść! Puść mnie! (ACK, 256)

W powieści określanej przez krytyków jako baśń, parodia powieści produkcyjnej, groteska, quasi-pastisz ${ }^{40}$ wątek romansowy („,kobiecy”) jest wyraźnie wyłączony i funkcjonuje na innych zasadach niż „męskie” ukształtowanie świata przedstawionego. Konstruując romans, Mach „uniknął ironicznego dystansu autora [...] potraktował go ze zbyt wielką, miejscami irytującą powagą" ${ }^{41}$. Skonstruowane jako kobiece spojrzenie jest, przypuszczam, wynikiem „sublimacji osobistych motywów psychologicznych” - w ściśle binarnym świecie, jaki znał Mach, nienormatywne (homoerotyczne) pragnienie kodowane jest jako kobiece i pisarz, czyniąc młodą kobietę główną i tytułową bohaterką powieści, a zarazem ukazując ją jako trudno mieszczącą się w tradycyjnych podziałach panujących w Chrobrzyczkach, w gruncie rzeczy otwiera sobie możliwość opowiedzenia o własnej, zakazanej fascynacji męskością i własnej - rozrywającej binarny porządek płci i seksualności - podmiotowości.

Punktem przecięcia antynomii powieściowych jest męskość i będące przedmiotem oglądu męskie ciało. To drugie jest jednoznacznie pociągające

40 Określenia genologiczne pojawiające się w recenzjach powieści, czasem sprzeczne wewnętrznie, podaję za: A. Fiut, op.cit., s. 129.

${ }^{41}$ Ibidem. 
i nacechowane erotyzmem, choć, a może właśnie dlatego, że niebezpieczne. Ta pierwsza odpycha - przynajmniej na poziomie społecznej świadomości gdyż zagraża ładowi, porządkowi, pokojowi, emancypacji kobiet, konserwuje porządek przed- i wojenny, jest despotyczna (ACK, 198-199). Męskość taka, jak rozumie ją Bałcz, zamknięta w przestrzeni relacji homospołecznych, jest skupiona na celebracji bohaterstwa, nastawiona na wojnę, ekskluzywna, anachroniczna, niedostosowana, społecznie zaburzona, straumatyzowana i toksyczna. Jako taka musi być pokonana, przezwyciężona, jej tak przecież względna i ograniczona do Chrobrzyczek hegemonia musi zostać złamana. Taki jest wymóg czasów, taki jest wyrok historii. Jednocześnie jednak jest w niej, a właściwie w tym, jak Bałcz ją ucieleśnia, pewien tragizm, pociągająca wzniosłość, szczególnie gdy - tak jak w przypadku Bałcza zdolna jest do transgresji, do zrozumienia własnego ograniczenia, niedostosowania, wewnętrznie dobra etycznie. Widać to szczególnie w kontrastowo przedstawionym młodym lekarzu, który również zabiega o względy Agnieszki. Tuzinkowy karierowicz, płaska osobowość nowych czasów. Podczas jego wizyty w Chrobrzyczkach Bałczowi udaje się go wraz z towarzyszącym personelem upić. Pijanemu medykowi pokazuje sztukę władania lassem (łapie na nie nieprzytomnego z pijaństwa asystenta lekarza), a potem, sam będąc pod wpływem alkoholu, prowokuje lekarza:

- Doktorku - ocknął się Bałcz. Podbiega do ściany, zrywa z kobierczyka staroświecką szablę, wkłada ją Stachowi w rękę - A bić się chcesz? Bij się! Bij - lecz doktor nie reaguje na wezwanie i Bałcz odrzuca szablę daleko w kąt. - Bzdura!

- A wojnę ty znasz? Nie znasz? O-o, Kolumbie! Lalusiu! - zdejmuje ze ściany fotografię, staje pod lampą, ogląda z bliska. - To byli ludzie! Byli! - nie ma. Bzdura (ACK, 308).

Melancholijna i podniosła, choć niebezpiecznie ocierająca się o groteskę czy autoparodię scena wypływania na jezioro w łodzi opuszczającego Chrobrzyczki Bałcza, pełna elegijnego patosu i ustylizowana nieco na pogrzeb wodza, stanowi zwornik tych dwu sprzecznych nurtów formujących powieść i zawartą w niej wizję męskości, męskości, która musi odejść, ale której nie ma co ani kto zastąpić. Niestety, nie da się ocalić erotycznie pobudzającego męskiego ciała, eliminując męskość - dlatego Bałcz znika z powieściowego horyzontu i odpływa w siną dal, a Agnieszka, wyrzekłszy się własnych pragnień, skazując się na samotność i w pewnym poczuciu psychologicznej klęski, podejmuje swoją społeczną misję nauczycielki.

Paweł Leszkowicz, analizując artystyczne przedstawienia męskiego nagiego ciała w polskiej sztuce, zwracał uwagę, że:

[...] w kulturze polskiej drugiej połowy XX wieku erotyka i estetyka męskości miała wywrotowy $\mathrm{i}$ alternatywny charakter. Podobnie jak w teorii estetycznej 
Edmunda Burke, w PRL-u cechy te powiązano z kobiecością, zostały natomiast programowo usunięte $\mathrm{z}$ męskiej podmiotowości i cielesności. W PRL-owskiej estetyce męskie ciało stało się sferą niewyrażalną, a zatem prawie związaną $\mathrm{z}$ wzniosłością, deformowaną w przedstawieniach i w wielu realizacjach wręcz przerażającą w swej antytetycznej ekspresji. Był to rezultat totalitarnego systemu, nie tylko politycznego, ale i seksualnego, podporządkowanego twardym regułom heteronormatywnego patriarchatu, które obowiązywały i po 1989 roku $^{42}$.

Czytana dziś - skomplikowana genologicznie, strukturalnie i intertekstualnie - ostatnia powieść Wilhelma Macha ujawnia to, do czego dostępu nie mieli jej ówcześni czytelnicy: jej skopofilia zogniskowana wokół budzącego pożądanie męskiego ciała bohatera, której wyrazem są spiętrzone opisy, w jakie popada narracja, ,wydobywa" męskiego bohatera z przestrzeni relacji homospołecznych (te są ośmieszane) i ustanawia „egalitarne” (choć niemożliwe do praktycznej realizacji) warunki relacji erotyczno-miłosnej:

Więc to jest Zenon Bałcz, tak się nazywa ten ciemny pionowy kształt, ta znikoma objętość ciała i odzieży, niewiele większa, mniejsza czy odmienna niż miliony innych, ta cząstka przestrzeni wypełniona w boleśnie jedyny, niepowtarzalny sposób; z pozoru tylko podobny do innych wypełnień przestrzeni.

Dlaczego, dziwi się i przeraża Agnieszka, muszę patrzeć i myśleć tak, jak nie patrzyłam i nie myślałam nigdy. [...] Wolno jej zatem być tu, w tej chwili, myśleć o nim. Patrzeć na niego. Jak oto budzi się z nieruchawej zadumy. Prostuje się, podnosi głowę (ACK, 243-245).

Skoncentrowanie na fantazjach dotyczących męskiego ciała przekracza tradycyjną heteronormatywną ideologię, która tłumi takie doznania, oraz podważa konwencjonalną pozycję kobiecego obiektu pożądania, typową dla patriarchalnej kultury - ta parafraza opinii Pawła Leszkowicza dotycząca Johanna J. Winckelmanna, autora Myśli o naśladowaniu greckich rzeźb i malowidet, zupełnie daje się zastosować do Agnieszki, córki Kolumba. O ile jednak u Winckelmanna ,antyczne fantazje były jedynym językiem pozytywnej ekspresji homoerotyzmu”43, o tyle Mach „,przemyca” uerotyzowane spojrzenie na mężczyznę w powieści społecznej, adresowanej do jak najszerszej publiczności. Mach umieszcza swoje queer gaze w powieści intencjonalnie jak najbardziej popularnej i zręcznie lawirującej między oczekiwaniami władzy a kontestacją „kombatanckich” norm męskości, wyznaczanych przez ideologię „Polski moczarstwowej”, napisanej na wyraźne zamówienie społeczne jako „romans dla wsi i o wsi”44. Mężczyzna nie jest tu stroną aktywną, a ści-

42 P. Leszkowicz, Nagi mężczyzna. Akt męski w sztuce polskiej po 1945 roku, Poznań 2012, s. 24-25.

43 Ibidem, s. 22.

44 Cyt. za: J. Poradecki, op.cit., s. 185. 
ślej mówiąc - jego aktywność okazuje się chybiona (Agnieszka odrzuca jego oświadczyny, próba wzięcia jej siłą też nie odnosi skutku), bohaterowie stoją u progu przemiany obyczajowej i, by posłużyć się parafrazą tytułu rozprawy Anthony'ego Giddensa, przemian intymności, których jeszcze nie rozumieją. Nowy kontrakt płci, nowy kształt gender ${ }^{45}$ wymagają nowych zachowań, których żadne z bohaterów jeszcze nie opanowało, szukają ich, błądząc, po omacku.

Choć powieść okazała się raczej artystyczną porażką - przeładowana sensami, dociążona sprzecznymi znaczeniami, rozerwana intencjami nie do pogodzenia, przerafinowana w swojej prostocie - właśnie dzięki tym wadom pozostaje ciekawym dokumentem epoki, świadectwem w rozpisanej na wiele głosów historii płci. Historii pełnej rozszczelnień, nieciągłości, załamań, zasługującej na rewindykację nadto pozornych oczywistości i monolitycznych wyobrażeń na jej temat.

\section{Bibliografia}

Bal A., Wilhelm Mach. Pisarz z Kamionki, Kamionka 2016.

Courtine J.-J., Introduction. Impossible virilité [w:] Histoire de la virilité, vol. III: La virilité en crise? XXe-XXIe siècle, sous la direction de J.-J. Courtine, Paris 2011.

Czapliński P., PRL i sarmatyzm [w:] (Nie)ciekawa epoka. Literatura i PRL, red. i wstęp H. Gosk, Warszawa 2008.

Czapliński P., Resztki nowoczesności. Dwa studia o literaturze i życiu, Kraków 2011. Czerwiński M., Przemiany obyczaju, wyd. II, Warszawa 1972.

Dutton K.R., The Perfectible Body: The Western Ideal of Male Physical Development, New York 1995.

Fiut A., Dowód nietożsamości. Proza Wilhelma Macha, Wrocław 1976.

Gawin D., Krytyczny patriotyzm. Próba bilansu, http://www.omp.org.pl/artykul. php?artykul=82 [dostęp: 21.11 .2017$]$.

Głowiński M., Jak pisać o Polsce Ludowej? [w:] Opowiedzieć PRL, red. K. Chmielewska, G. Wołowiec, Warszawa 2011.

Grzelecki S., Ostatni kombatant, „Życie Warszawy” 1964, nr 284.

Koźniewski K., Rozmowa! O czym?, „Polityka” 1964, nr 41.

Leszkowicz P., Nagi mężczyzna. Akt męski w sztuce polskiej po 1945 roku, Poznań 2012.

Mach W., Agnieszka, córka Kolumba, Warszawa 1965.

Mach W., Szkice literackie, t. II: W Polsce i w świecie, Warszawa 1971.

Maciąg W., Literatura Polski Ludowej 1944-1964, Warszawa 1973.

45 Emancypacja Agnieszki zostaje wpisana w ideologiczny aparat państwa - nauczanie, co znacznie ogranicza jej skalę, zasięg, zamyka szereg potencjalności. 
Poradecki J., Pisarstwo Wilhelma Macha, Warszawa 1984.

Ritz G., Iwaszkiewicz, Breza, Mach. Niewypowiadalne pożadanie a poetyka narracji, przeł. A. Kopacki [w:] idem, Nić w labiryncie pożądania. Gender i płeć w literaturze polskiej od romantyzmu do postmodernizmu, Warszawa 2002.

Śmieja W., Homoseksualność i polska nowoczesność. Szkice o teorii, historii i literaturze, Katowice 2015.

Takie będa Rzeczpospolite. Wspomnienia i wypowiedzi nauczycieli, oprac. i wstęp J. Szczawiej, Warszawa 1962.

Theweleit K., Męskie fantazje, przeł. M. Falkowski, M. Herer, przekład przejrzał A. Żychliński, Warszawa 2015.

Toeplitz K.T., Agnieszka ‘46, ,Świat” 1964, nr 50.

Tomasik K., Homobiografie, wyd. II zm. i poszerz., Warszawa 2014.

Załuski Z., Twój brat - zbir [w:] idem, Siedem polskich grzechów głównych. Nieśmieszne igraszki, wyd. V, Warszawa 1973. 